\title{
Hadith Corpus
}

\section{The Fluid Boundaries of HADITH}

It is important to recognise that the science of hadith collection that developed in the ninth century and ultimately gave us the completed traditional collections of hadith more than 300 years $^{1}$ after the Prophet's death in the year $\mathbf{6 3 2}$ was an extraordinarily painstaking task undertaken by the most committed men of faith within mainstream, or Sunni, Islam. It is also important to highlight that the boundaries of this body of knowledge have never been fixed, with some referring to The Four Books of hadith, for example, others to The Six Books, and yet others to five or even eight ${ }^{2}$ books. The most referenced six books ${ }^{3}$ in Sunni Islam are by the following hadith scholars:

- Bukhari (d. 870)-The famous compilation known as the Sabih of Bukhari is said to contain 7379 hadiths with full chains of transmission, but given repetitions and different versions of the same report,

${ }^{1}$ Barlas, Asma. 2015. Believing Women in Islam: Unreading Patriarchal Interpretations of the Qur'an. Texas: University of Texas Press, 44.

${ }^{2}$ Oliveti, Vincenzo. 2002. Terror's Source: The Ideology of Wahhabi-Salafism and its Consequences. Birmingham, England: Amadeus Books, 28-29.

${ }^{3}$ Brown, Jonathan. 2014. Hadith: Muhammad's Legacy in the Medieval and Modern World. London: Oneworld Publications, 31-34 provides the ensuing summary descriptions of the six books of Sunni hadith collections. 
the actual number of Prophetic traditions is approximately 2602. The compilation also includes Bukhari's own comprehensive vision of Islamic law and dogma, backed up with relevant hadiths. The author also often includes his own commentary, and the commentary of Companions of the Prophet and later figures, on a given hadith. Bukhari did not claim that his compilation contained all reliable hadiths, but that he had focused on those relevant to his legal discussions.

- Muslim (d. 875)-The Sabih of Muslim collection contains nearly 12,000 hadiths but again given repetitions and multiple versions of the same report, the actual number of Prophetic traditions is estimated at around 4000. Muslim's compilation is more of a pure hadith collection than Bukhari's, containing no legal commentary by the author or commentary by any of the Prophet's Companions or later figures.

The compilations of Bukhari and Muslim have 2326 hadiths in common. Both men were students of the renowned scholar Ibn Hanbal. Both men broke with the then-prevailing willingness to use weak hadiths in law-in other words, by the ninth century some laws had already been established and labelled "Islamic" despite their weak links to Islamchoosing to focus only on hadiths with chains of transmission that they felt met the requirements of authenticity i.e. sahih, hence the two men's stature in Islamic history. However, both men nonetheless were more concerned about authenticating a report's chain of transmission than about assessing or validating its content as such, which will be discussed in Chap. 3, "Hadith Content".

The other four compilations also focus on hadiths with strong chains of transmission, but contrary to Bukhari's and Muslim's, they include had$i$ ths that the authors openly acknowledge as unreliable. These unreliable hadiths might be labelled, among other categorisations, as "weak" or as "acceptable but unusual", the latter usually indicating that the chain of transmission seemed sound but the meaning less so due to lack of corroboration.

- al-Sijistani (d. 889)—The Sunan of Abu Dawud, as this scholar who was also a student of Ibn Hanbal is commonly known, is a compilation focused on hadiths used to derive law which cites around 4800 hadiths. As indicated above it does include weak hadiths but also alerts the reader as to which ones they are. 
- al-Nasa'i (d. 915)—Two Sunan compilations were produced by this scholar: the larger one contains many hadiths the author acknowledged as unreliable, while the smaller one consists only of the 5750 that he considered reliable.

It is the Sabih collections of Bukhari and Muslim, and the Sunan collections of Abu Dawud and al-Nasa'i, that are often referred to as the four "core" books of hadith in mainstream or Sunni Islam.

- al-Tirmidhi (d. 892)-A student of Bukhari's, the Jamis of alTirmidhi contains around 3950 hadiths and also focuses on hadiths used to derive law. He also does alert the reader to unreliable hadiths that he includes in his work.

- Ibn Majah (d. 887)-In the Sunan of Ibn Majah compilation, the author actually attempts to include only reliable hadiths as far as chains of transmission go, but later Muslim scholars noted that as much as a quarter of his 4485 badiths were in fact unreliable.

The collections of al-Tirmidhi and Ibn Majah are the most often cited as forming part of The Six Books alongside the core four, but not always. And as indicated above, some will speak of five or eight books. Among the other scholars' works cited as references are those by Ibn Hanbal, Ibn Khuzaima, al-Daraqutni, al-Kurasani, al-Darimi and Malik bin Anas, the last three (Malik's in particular) being among the earliest compilations, to mention a few.

Between them, the Six Books of Bukhari, Muslim, Abu Dawud, alNasa'i, al-Tirmidhi and Ibn Majah are believed to contain no less than 19,600 different hadiths of the Prophet, yet their authors never claimed that they contain all hadiths. Nor did they claim that every hadith included in their books has a reliable chain of transmission, and indeed a huge number of other reports can be found in other works. ${ }^{4}$

Mention must also be made of the Shia corpus of hadith reports which was compiled two centuries after the Sunni compilations in the eleventh century, since approximately $10 \%$ of the world's Muslims belong to one of the Shia denominations within Islam. The primary Shia hadith

${ }^{4}$ Ibid., 58. 
corpus (of the Imami or Twelver denomination) partially overlaps with the Sunni hadith corpus, including a notable overlap in transmitters, ${ }^{5}$ but it also includes significant other material from the Prophet's family members and early descendants, also to be discussed in the next chapter on content. Here, one can speak of The Four Books of Shia hadith collections ${ }^{6}$ by the following scholars:

- al-Kulayni (d. 939) - This compilation addresses all legal topics relating to the life of a Muslim, and the nature and origins of the Shia imamate. It is structured, like Bukhari's compilation, to deliver lessons to the reader, and claims to only include authentic hadiths.

- Ibn Babawayh (d. 991)-This collection is a comprehensive one by topic. The author does not provide full chains of transmission for the hadiths cited, but claims that only hadiths that are authentic are included.

- al-Tusi (d. 1067)-Two collections were produced by this scholar. The first is more of a commentary on a legal work by another scholar that focuses on that work's hadith citations. The second is devoted to sorting out and reconciling conflicting hadiths. Both books adopt a more rigorous approach to hadith authentication than al-Kulayni's or Ibn Babawayh's.

The above landscape tour of the hadith corpus is relayed here simply to highlight that from the beginning, there was a vast amount of information to wade through and a very real element of temporal distance from the Prophet, so that the body of hadith reports necessarily remains fluid and the study of hadith can never be an exact science, despite our collective best efforts.

In addition, the early hadith scholars were typically contemporaries who were also acquainted with one another, sometimes as each other's students or as peers who shared a central teacher. This means that the widely recognised hadith compilations developed in the ninth and officially finalised in the tenth century came out of a specific time,

${ }^{5}$ Ibid., 137-142.

${ }^{6}$ Ibid., 129-131, including for the ensuing summary descriptions of the four books of Shia badith collections. 
place and environment and not, as I had assumed growing up, from the Prophet's time, place and environment of the seventh century.

\section{The Factual Case for the Qur'an Compared}

\section{TO HADITH}

By contrast, the Qur'an does come to us from the Prophet's own time, place and environment. Its verses were memorised and written down on parchments as they were being revealed over the course of the 23 years of revelation-and not 200 or 300 years later-by early Muslim scribes, several of whom were among the Prophet's closest Companions. The scribes also received instruction from the Prophet near the end of his life regarding the order in which verses should be arranged, instruction he had in turn received from the archangel Gabriel, at which time he is known to have also recited the book in its entirety twice to them to ensure every word had been captured accurately.

Two years after the Prophet's death, in the year 634, the Companion and first caliph Abu Bakr ordered the gathering of the Qur'anic verses into a single volume to prevent their loss, as the first generation of Muslims who knew it all by heart, which included those who had served as its scribes, were dying off. Around the years 650-651, a new compilation was completed on the order of another Companion, the third caliph Othman, after he noticed slight differences in the pronunciation of the text as Islam spread beyond the Arabian Peninsula to non-Arab lands. This Othman compilation was based on Abu Bakr's volume and the two are accepted by Muslim scholars as being the same, only Othman's version provided the form that became the standard and that has been promulgated throughout the world to this day.

Thus around 19 years after the Prophet's death, the standardised Qur'anic form we know today was produced, based on the volume pulled together two years after the Prophet's death. Non-Muslim scholars agree with their Muslim counterparts that the Qur'an today presents the original verses as recited by Muhammad to his followers. ${ }^{7}$

As chance would have it, I visited a magnificent exhibition in February 2017 at the Smithsonian's Freer|Sackler Gallery in Washington, DC entitled "The Art of the Qur'an", where an impressive array of early versions

\footnotetext{
${ }^{7}$ Lang, Jeffrey. 1995. Struggling to Surrender: Some Impressions from an American Convert to Islam. Maryland: Amana Publications, 90.
} 
of the Qur'an was on display. It was there that I first learned that early Arabic scripts such as the Hijazi script of the Othman era did not employ dots on letters that would help distinguish between two or more otherwise identical letters-I had certainly seen such unintelligible script before but just not thought much about it. A dot (or two or three) placed above or below a letter can make all the difference in Arabic as it can distinguish between several letters at a time. To demonstrate the point, consider that no dot above a certain letter yields rahim (merciful) whereas one dot below the same letter in the same word yields rajim (accursed).

Nor did the early scripts show marks to indicate vowels, a less problematic omission for a native Arabic reader but still a significant challenge for easy or correct understanding when it comes to scripture, given its condensed articulation of unlimited divine wisdom into words that our relatively limited human minds can handle. ${ }^{8}$

This early absence of direction from dots and vowels made a reader's ability to correctly pronounce and therefore understand certain Qur'anic verses dependent on having access to the background or historical context of some verses, which is why the scribes often included notes to go with the verses they were writing down. Little wonder then that Qur'anic calligraphic script, such as the relatively early Kufi script, soon evolved, first by introducing the dots and then by adding the marks indicating vowels, from the end of the seventh century on.

\footnotetext{
${ }^{8}$ The great metaphysician of the twentieth century, Frithjof Schuon expressed this intuitively brilliant explanation of the complexity of the Qur'an and indeed all scripture in several of his writings. It is reminiscent of St Augustine's description of why scripture does not yield itself to the casual reader, requiring a genuine desire to understand for the layers to start peeling off.
} 
Open Access This chapter is licensed under the terms of the Creative Commons Attribution 4.0 International License (http://creativecommons.org/licenses/ by $/ 4.0 /$ ), which permits use, sharing, adaptation, distribution and reproduction in any medium or format, as long as you give appropriate credit to the original author(s) and the source, provide a link to the Creative Commons licence and indicate if changes were made.

The images or other third party material in this chapter are included in the chapter's Creative Commons licence, unless indicated otherwise in a credit line to the material. If material is not included in the chapter's Creative Commons licence and your intended use is not permitted by statutory regulation or exceeds the permitted use, you will need to obtain permission directly from the copyright holder.

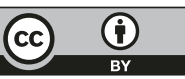

